\title{
Second-home tourism present and future. The case of Greece.
}

\author{
Vagena Akrivi \\ $\mathrm{PhD}$, Department of Business Administration, University of Patras, Rio Achaia, Greece.
}

\begin{abstract}
:
Second home tourism is a rapidly growing form of tourism around the world. Being an integral part of rural areas and their history, second homes are an established example of the post-productive consumption of the countryside. The expansion of urbanization and the pressures of the urban way of life, as well as the search for a pleasant climate and clean environment, have contributed particularly to the development of second home tourism globally.

This study intends to investigate the present, the future and the impact of second home tourism on destinations, local people and tourists. The development of second home tourism, or tourist home is, undoubtedly, a strongly evolving social phenomenon. Activated by economically developed societies and is linked to income growth, urbanization, the possibility of geographical mobility and the increase of leisure time. This phenomenon operates and intensifies, almost in parallel with tourism.

Also, the study investigates the effects of second home tourism in Greece, a very popular destination for international and domestic tourism. The country has been experienced a high growth of second home tourism in the last few years.
\end{abstract}

Keywords: Greece, Second home tourism, Digital Nomads, Destinations, Sustainable Tourism Development

\section{Introduction}

Second homes are a significant issue in rural planning and policy according to Adamiak C. et al. (2015). They are also an increasingly popular subject of research in tourism and rural studies as an interdisciplinary and multifaceted phenomenon (Hall \& Müller 2004; McIntyre et al. 2006; Roca 2013; Hall 2014). In economic terms, second homes are often seen as important contributors in local economies, and this can be especially important in the case of depopulating of rural areas. However, second homes can also have a negative social impact on destinations, including potential conflicts and poor cooperation between seasonal and local populations. Hall (2015) is arguing that this can happen especially when there are significant differences in attitudes and values of permanent residents and second-home residents and where there are substantial restrictions on the availability of housing stock. The landscape and the environment, which usually attract second homeowners to specific areas, are subject to simultaneous transformations produced by the development and use of second homes. It is also increasingly observed that the practice of governance needs to be adapted for mobile populations and multi-dwelling practices due to Adamiak C. et al. (2015).

At the same time, tourism and the tourism industry have undergone significant changes associated with broader individual lifestyle choices. People sometimes move in ways that challenge the traditional identifications and categorizations based on, for example, tourists and tourism as Gustafson (2002) points. With the development of the common economy and alternative ways of working and travelling, modern 
Tourists are increasingly interested in "being at home" and "going locally" while travelling to various destinations. Second-home tourism was at the forefront of these changes providing ways to engage in leisure activities that contrast with mass tourism, Hannonen O. (2018).

Also, about the reasons that led to the development of the phenomenon of second home tourism, Rye (2011) argues that in the context of the change of rural areas, it has been perceived as a positive socioeconomic project. This is because the dependence of rural areas on the primary sector has weakened due to globalization and economic restructuring. Whereas the countryside traditionally relied on exports of commodities by the primary industries such as agriculture, fisheries, and extractive industries, to urban markets, it has become increasingly characterized by its role as producer of rural services, experiences, and quality of life. It is no longer only a site of production but as much a product in its own right according to Habib Alipour, Hossein G.T. Olya b, Bahareh Hassanzadeh and Hamed Rezapouraghdam (2017).

The growth of budget airlines has increased connectivity between places mostly due to profoundly modified tourism consumption: "mass tourism has ceased to be confined to a radius of a few hundred kilometres around the areas of departure. Many people in Northern Europe have winter vacation in the Canary Islands, Costa del Sol, Majorca, Morocco, Tunisia, Greece, or Cyprus" (Claval, 2013). Second homeowners utilise these affordable routes to the south of Spain and the Canary Islands, which provide easy access to their foreign homes (Casado-Diaz et al., 2004). Among other significant factors inducing international mobility is the proliferation of information on the Internet, the digitalisation of real estate, as well transnationally operating estate agencies that make information about foreign housing markets more readily available (Gustafson, 2009).

However, in this discussion, the negative impacts of second home tourism cannot be overlooked, as it generates immense socio-cultural and environmental costs (Gallent, 2014; Hall and Müller, 2004; Jeong et al.,2014). While second home tourism is inherently dependent upon the sustainability of the natural environments in which they occur (Long and Hoogendoorn, 2013) most of the studies on second home tourism have not addressed the negative environmental impacts in a regional context (Huhtala, and Lankia, 2012; Jeong et al., 2014; Orueta, 2012).

\section{Materials And Methods}

This is a conceptual paper and as such it does not directly involve primary data collection but analysing related papers and documents. It also draws from the experience of the second and third authors, who have conducted research.

The paper aims to critically review existing literature and help professionals and researchers to better understand, manage and valorize the second home tourism impacts and transformational affordance of this phenomenon.

To achieve this, the study conducts a review of the academic literature, explores the growth of second home tourism and will describe the future trends in this area. It will then refer to the case of Greece, will try to evaluate the second home tourism phenomenon and analyse how the market is shaped and its conditions in the country.

\section{Discussion:}

\section{Second home tourism and policies}

Oman \& Arndt, (2010) define governance as a complex kind of management, which involves public or private profit or non-profit organizations. It is a result, they say, of the involvement of different actors in the decision-making process. Governance shifted the attention from strictly economic aspects of the State to a broader view, which involves social and political dimensions of public administrations. of Tourism 
governance, the complexity is also huge. Tourism is a fragmented sector, with several types of actors and specific institutions that interact with each other, in some activities that only occur where the service is provided, is formed largely by small and medium enterprises. According to Ritchie and Crouch (2003), a tourism destination distinguishes several types of areas, a country or a macro-region consisting of several countries, a region, a town or a unique place with attraction capacity.

The rapid development of second home tourism has led to a new tourism trend, especially among the middle class which desires to enjoy tranquillity away from the urban environment (Fanni, 2006; Tilaki et al., 2013). With the rapid growth rate of the urban population (Kazemipour and Mirzaie, 2005; The World Bank Group, 2015), the ground has become favourable for the revitalization of real estate companies which seem to be taking advantage of the advantage of such non-regulated markets. Therefore, many accommodations complexes (leisure apartment buildings) and single second homes have sprung up in various urban and nonurban areas. The growth of the second home sector gives rise to a number of new challenges, conflicts and contestations in communities according to Rye, (2011). The plethora of tourism interests highlighted new areas, new values and orientations, stimulating new alternative forms of tourism, as well as Airbnb. This means, having the tourist the possibility of staying alone or together with the owner in an intimate, is a habit of hospitality that did not exist in previous years. The way of stay is changing, hotels are no longer the absolute choice and tourists choose to stay in homes that they rent.

However, we should not forget to mention the fact that the development and diversification of the tourism phenomenon have created the need for an organizational and legislative framework that includes all activities related to it. These regulations, in the case of Airbnb, have been designed and implemented by the company itself to ensure confidence, elimination of risk and transparency (Kavoura A.; Kefallonitis E.; Giovanis A., 2019).

Said C. (2012) argues that besides, for the proper functioning of any organized function, especially when there are a lot of people involved, it is necessary to have appropriate organizational and legislative arrangements that will be able to contribute to the protection of the interests of all parties.

Ultimately, the institutional requirements imply that second home tourism remains a challenge for local municipalities and regions Lars Larsson \& Dieter K. Müller (2017).

One of the main attractions of buying property in Greece is its Golden Visa Policy. This grants a five-year residency permit to foreigners investing in property in the country. You'll need to spend at least $€ 250,000$ on your home, and meet other criteria such as having health insurance and no criminal record. Once granted, the holder of a Golden Visa and their immediate family members can legally live and work in Greece. However, you aren't actually required to live there and you can choose to rent out your purchased property if you like. If you do settle in Greece, you can apply for citizenship once you've lived there for seven years. Or, you can simply renew your residency permit (Zorica Lončar, 2021).

How much does it cost to buy property in Greece?

\begin{tabular}{|l|l|l|}
\hline \multicolumn{1}{|c|}{ Area } & \multicolumn{1}{c|}{ Cost of apartment } & \multicolumn{1}{c|}{ Cost of detached house } \\
\hline Athens & $€ 200,000-400,000$ & $€ 1$ million+ \\
\hline Thessaloniki & $€ 70,000+$ & $€ 100,000+$ \\
\hline Chalkidiki & $€ 70,000+$ & $€ 150,000$ \\
\hline Crete & $€ 70,000+$ & $€ 350,000$ \\
\hline Corfu & $€ 100,000-200,000$ & $€ 300,000+$ \\
\hline
\end{tabular}




\section{Second home tourism in future}

Dieter K. Müller (2021) says the recent COVID-19 pandemic has entailed new and somewhat unexpected attention to second homes. Travel restrictions have rejuvenated the interest in second homes as they provide an opportunity for close-to-home tourism, which also aligns with concerns regarding the impact of travel on climate change. Also, the pandemic has manifested that online work from home offices can serve as a substitute for, for at least supplement, traditional work patterns for an increasing number of people. Tourists can use digital technology to increase their working effectivity and productivity while enjoying the tourist destination. This situation creates many freelance workers. These people are called the digital nomads. This insight opens up new opportunities to utilize second homes, and may indeed entail a step toward a truly multilocal and mobile society (Vagena A. 2021). These people are mainly renting second homes for their stays. Second-home research can be a forerunner in understanding such new spatial-temporal arrangements.

The COVID-19 pandemic has become a factor affecting the tourism industry in many aspects. Second homes, which meet a significant part of the accommodation within the tourism sector, have also been affected on different levels by this pandemic says Inanir (2021). As Zogal et al (2020) describes, due to the risk of spreading the virus of the Covid-19 pandemic, there have been migrations from crowded places to less populated rural areas with the travel bans being relaxed during the summer period. In this process, the second homes, which have types such as holiday homes, cottages, recreational houses, bungalow houses, time properties, villas, cottages, cabins, summer houses, summer residences, chalets, entertainment houses, highland houses, village houses and winter houses, have started to become even more attractive in terms preventing close contact. Depending on this situation, just like all over the world, second homes have become more preferred places by many guests than large-scale hotels in Greece.

\section{The case of Greece}

According to data released annually by the Association of Greek Tourism Enterprises (SETE) and the Bank of Greece, tourism is a major contributor to the Greek economy and a sector of rising competitiveness at the global level. The increasing number of tourists and the evolving profile of today's travellers demand new ideas and infrastructure projects. In Greece, investors will find a wide spectrum of opportunities, a friendly environment, and some of the most beautiful locations in the world. According to Zorica Lončar (2021), after impressive growth in 2019, house prices in Greece are once again on the rise - albeit very slowly. Urban areas of the country saw a modest $3.38 \%$ rise in prices in 2020 . Greece's property market will pick up as the country's economy recovers from the pandemic.

Although the country's tourism infrastructure is well developed, Greece is committed to establishing itself as a 12-month destination. Its Mediterranean climate is ideal for activities such as year-round golf and trekking and it is estimated that one million Europeans would consider Greece as a second home destination.

A study by the University of the Aegean (Nikolara A. 2019) says that many researchers use the term "subversive economy" to describe every situation in which an industry sector is crushed and all previously successful and active stumbles. The term "disruption" describes a process where a company with fewer resources can compete for successfully in-service enterprises. Subversive economies start with neglected market segments or new markets. They create a market where they didn't exist or find a way to turn noncustomers into consumers.

What do we know of the practices and motives of multiple dwellings of different groups of people? How do multiple dwellings impact local communities and housing structures? What are the environmental impacts of second homes and how do the impacts compare with other types of tourism? How are multiple dwellers and second homes are taken into account in rural municipalities? These questions are pending answers. 
Mediterranean countries attract many types of tourism, particularly oriented to the enjoyment of the climate, the sun and the sea. These mass flows are seasonal and vulnerable to political, environmental and health crises and circumstances, as has recently been shown by the losses due to the covid-19 pandemic, Vagionis N. \& Leontidou L. (2020). This is why the tourism model is changing internationally and creating new opportunities for countries that will perceive it timely and respond directly to the challenges of the new "era". The development of second home tourism can contribute to the emergence of new destinations that in the past have not developed as much as they should have had a positive impact on the values of real estate in the region concerned, while at the same time it can be an opportunity to directly link tourism with the real estate Michael Hall C. (2014).

The benefits for the Greek economy seem to be multiple through indirect and direct taxes. It will also make a positive contribution to the economy of the region concerned both through investment and through job growth Karayiannis O., Iakovidou O and Tsartas P. (2013).

In Greece according to the last record of the Hellenic Statistical Authority (2011), of the country's regular residences, $64.7 \%$ are inhabited and $35.3 \%$ are vacant. This ranks the country in one of the EU countries with high rates of empty houses. Also, countries in the same situation are Portugal with 31,9\%, Malta with $31,8 \%$, Bulgaria with $31,4 \%$ and Cyprus with $31,1 \%$.

The always strong tourism industry in Greece is leading more and more homeowners, in conjunction with the large taxation of property, especially due to the economic crisis, to take advantage of their furnished homes or villas for tourism. As a result, the institution of second home tourism has found an important place in the market. It is expected that in the coming years this institution will be one of the main axes of the tourism industry and the economy that will differentiate the Greek tourism product. High prices in popular destinations such as Mykonos and Santorini are turning foreign property investors towards new areas, according to the latest analysis of the real estate consulting firm Algean Property (2020), for the purchase of a second home for tourism use. The analysis notes that the shift of prospective buyers of holiday homes to new destinations is linked both to the continuous increase in tourist flows and to the benefits it brings to short-term tourist rentals residences. Mykonos, Santorini and Paros are high in the preferences of foreign buyers, as they are more recognizable tourist destinations. However, other destinations throughout Greece are gaining a share, which now offers satisfactory returns to buyers such as Corfu, Rhodes, Halkidiki and Crete. In addition, due to the good course of tourism, more alternative destinations in the Peloponnese (such as Messinia), the Dodecanese (Kos and Symi) and the Ionian (Lefkada and Zakynthos) are gaining ground. According to the online newspaper euro2day (2020), the high performance of tourism on the one hand gave a significant boost to real estate returns, bringing to the surface areas such as the centre and the southern suburbs of Athens and Thessaloniki. In addition, the conditions were created for the development of the market of short-term tourist leases, giving life to the domestic real estate market ". In the top ten destinations for those looking for a holiday home are destinations such as Skiathos (with a yield of 6\%), Porto Heli (5.1\%), Rhodes, Halkidiki and Chania (4.8\%), faced with other extremely popular Mediterranean destinations such as Marbella (4.3\%), Nice (4.2\%) and Saint Tropez (3.9\%). Foreign direct investment in real estate in Greece, based on data from the Bank of Greece, reached 1.13 billion euros in 2018 with an explosion of $172.1 \%$ compared to 2017 , which amounted to 415 million.

In the first half of 2019 , according to Bank of Greece data $+0.38 \%$, foreign direct investment in real estate reached EUR 737 million. (almost twice the corresponding period in 2018), with estimates for the whole of 2019 bringing them up to EUR 2 billion.

The effects of the Covid 19 pandemic were evident in the market, according to Michas G. (2021), however, the interest of foreign investors in the Greek housing market remained high. On the contrary, the Greeks are 
holding a wait-and-see attitude mainly due to the collapse of short-term rentals following the shrinking of tourist arrivals. It is no coincidence that in 2020 real estate transfers in the Attica Region decreased by 49.5\%, compared to 2019, while in 2018 transfers had increased by 59.6\%. Experts estimate that from 2021 the demand for homes that are rented through Airbnb or offered in a different way to tourists will recover.

Second-home mobility is a complex phenomenon linked to tourism, changing housing needs, social factors, economic pressures, but also new potential for urban functions arising, Stergiou D. et al. (2017).

\section{Conclusions:}

Tourism planning and development projects are vulnerable to cultural, economic, environmental and social differences of host communities and tourists. Uncertainty about future results, the failure of traditional practices to deal with complex ethical issues, and the need to make "ethical choices and not just statistical calculations", call for broad, representative, inclusive and informed "Non-expert" involvement in community tourism planning and development as refers Grybovych et al., 2011.

Jaakson, (1986) and Roca, (2013) report that as a form of tourism, second homes are associated with terms such as routine and innovation, return to nature, confidence, continuity, work, elitism, ambition, time and distance, vacation home, holiday home and leisure home.

Similar to other forms of tourism, second home tourism contributes to capital inflows. Creates jobs and income for small businesses such as grocery stores, restaurants, services and leisure companies and construction companies (Hoogendoorn and Visser, 2015; Larsson and Muller, 2017; Visser, 2008). Second homeowners tend to have more disposable income than locals (Larsson and Muller, 2017). However, because people who invest in this form of tourism are mainly attracted to low property prices, this form of tourism is not very sustainable and can fluctuate according to macroeconomic changes (Muller, 2011), but also according to social and environmental conditions (Anabestani, 2014).

On the other hand, according to Nordbo,(2014) and Robertsson \& Marjavaara, (2015), second homeowners are a group that has multiple resources. It is also estimated that homeowners of second home tourism estates, contribute to the extension of the tourist season, to the increase of the quality of services, the change of demand as well as to the creation of a more stable base for business opportunities. This is because providers of such services often implement strategies for improved service delivery - and consequently increased revenue. The use of new knowledge and competence to stimulate innovation and development is considered essential for destinations, industries and individual enterprises (Hjalager, 2002; Cooper, 2006; Hallin \& Marnburg, 2008).

Private and public sector service providers adopt and develop coping strategies for business development and service delivery during the summer months and the high tourism season. Legislative bodies at the national level have a mandate to influence taxation, voting rights, spatial planning legislation, etc., whereas municipal actors can adopt strategies for hindering or promoting second homeowners through spatial planning practices or the provision of public services. it can be concluded that true integration requires action on not only a local level but also a national one (Overvag, K., \& Gunnerud Berg, N., 2011).

In terms of factors that create a positive environment in the destination for second home tourism, the following can be included: Political stability and security, beautiful countryside landscapes, natural and cultural resources, excellent second home amenities and residential areas, sports and entertainment opportunities. Also, the dimensions of people and communication and socialization were among the most important pull factors influencing the tourist's overall satisfaction level (Wong B.K.M. et al., 2017).

The Greek, tourist, investment environment enters into one new orbit, where luxurious, tourist complexes, following the demands of the times, promise to raise the level of quality of the tourist product, to offer a 
complete "package" of services, to attract high-income tourism and promote a new profile of the country abroad.

Greece and its islands have been among the most attractive destinations in Europe for years. In the last years, the Greek islands have attracted the intense interest of international buyers, especially from the countries of Central Europe. We expect that this number will increase exponentially in the coming months ", says George Petras, CEO of Engel \& Völkers in Greece. In the last twelve months, despite the coronavirus pandemic, property prices on the islands have remained stable and interest rates have soared.

International buyers make up about 85 per cent of potential buyers who own a second home property. Central Europeans from German-speaking regions (45 per cent from Germany, 15 per cent from Switzerland and 10 per cent from Austria), as well as from the Benelux countries and the USA. About 90 per cent of homeowners in the Greek islands are individuals who use their property as a second home (Newmoney 2021).

When the issue is a state policy, some problems seem to arise. The spatial distribution of the tourist phenomenon in the country presents in a very small degree differentiation, i.e. underdevelopment of all noncoastal forms, with tourist demand and supply basically concerning the most limited area and the most environmentally sensitive area of the coasts. The institutional framework enables the development of tourist accommodation throughout the territory, without particularly strict restrictions and criteria, even in geographical areas diagnosed with a strong concentration of tourism investments. This puts pressure on sensitive people environmental and cultural areas, Vagionis N. \& Leontidou L. (2020).

\section{References:}

1. Adamiak C., Vepsäläinen M., Strandell A., Hiltunen Mervi J., Pitkänen K., Hall C. Michael, Rinne J, Hannonen O., Paloniemi R., Akerlund U. (2015), "Second home tourism in Finland, Perceptions of citizens and municipalities on the state and development of second home tourism", Reports of Finnish Environment Institute 22en | 2015, Finnish Environment Institute

2. Anabestani, A. (2014), "Effect of second home tourism on rural settlements development in Iran", International Journal of Culture, Tourism and Hospitality Research, Vol. 8 No. 1, pp. 5873.

3. Casado-Diaz, M., Kaiser, C., \& Warnes, A. (2004), "Northern European retired residents in nine southern European areas: characteristics motivations and adjustment", Ageing and Society, 24(3), 353-381.

4. Claval, P. (2013), "Evolving Forms of Mobility and Settlement: Second Homes and Tourism in Europe", In Z. Roca (Ed.) Second Home Tourism in Europe: Lifestyle Issues and Policy Responses, Surrey. Ashgate.

5. Cooper, C. (2006), "Knowledge management and tourism", Annals of Tourism Research, 33(1), pp. 47-64. doi: 10.1016/j.annals.2005.04.005

6. Fanni, Z., (2006), "Cities and urbanization in Iran after the Islamic revolution". Cities 23 (6), $407 \mathrm{e} 411$.

7. Gallent, N., 2014. "The social value of second homes in rural communities", Hous. Theory Soc. $31(2), 174-191$.

8. Gallent, N., Mace, A., Tewdwr-Jones, M., (2005). "Second Homes: European Perspectives and UK Policies", Ashgate Publishing.

9. Gallent, N., Tewdwr-Jones, M., (2000). "Second homes and the UK planning system", Plan. Pract. Res. 16 (1), 59-69. 
10. Gustafson, P. (2002), “Tourism and seasonal retirement migration”, Annals of Tourism Research, 29(4), 899-918.

11. Gustafson, P. (2009), "Your home in Spain: Residential strategies in international retirement migration”, In M. Benson \& K. O’Reilly (Eds.), Lifestyle Migrations: Expectations, Aspirations and Experiences, Surrey, Ashgate.

12. Habib Alipour, Hossein G.T. Olya b, Bahareh Hassanzadeh and Hamed Rezapouraghdam (2017), "Second home tourism impact and governance: Evidence from the Caspian Sea region of Iran", Ocean \& Coastal Management 136 165-176, Elsevier

13. Hall Michael C. (2014), "Second Home Tourism: An International Review", Tourism Review International, Vol. 18

14. Hallin, C. A. \& Marnburg, E. (2008), "Knowledge management in the hospitality industry: A review of empirical research", Tourism Management, 29(2), pp. 366-381

15. Hannonen O. (2018), "Second home owners as tourism trendsetters: a case of residential tourists in Gran Canaria", Journal of Spatial and Organizational Dynamics, Vol. VI, Issue 4, (2018) 345 359

16. Hjalager, A. M. (2002), “A review of innovation research in tourism”, Tourism Management, 31(1), pp. 1-12.

17. Hoogendoorn, G. and Visser, G. (2015), "The economic impact of second home development in small town South Africa”, TourismRecreation Research, Vol. 35 No. 1, pp. 55-66.

18. https://www.bankofgreece.gr/statistika/agora-akinhtwn/meletes-kai-analyseis-gia-thn-ellhnikhagora-akinhtwn

19. https://www.euro2day.gr/

20. https://www.statistics.gr/en/home

21. Inanir A. (2021), "Second Home Tourism During COVID-19: The Case of Turkey", In book: Socio-Economic Effects and Recovery Efforts for the Rental Industry, Publisher: IGI Global

22. Jaakson, R. (1986), "Second-home domestic tourism”, Annals of Tourism Research, Vol. 13 No. 3, pp. 367-391.

23. Karayiannis O., Iakovidou O and Tsartas P. (2013), "Historic, symbolic aspects and policy issues of the second home phenomenon in the Greek tourism context: The Cyclades case study", In book: Second Home Tourism in Europe: Lifestyle Issues and Policy Responses (pp.201-234), Chapter: 9, Publisher: Routledge, Editors: Zoran Roca.

24. Kavoura A.; Kefallonitis E.; Giovanis A. (2019). "The Sharing Economy and How It Affects the Conditions of Consumption and Competition in the Tourism Industry: The Case of Airbnb in Greece.", Springer Proceedings in Business and Economics, Strategic Innovative Marketing and Tourism (7th ICSIMAT, Athenian Riviera, Greece, 2018) 10.1007/978-3-030-12453-3(Chapter 10), 85-92. doi:10.1007/978-3-030-12453-3_10

25. Kazemipour, S., Mirzaie, M., (2005), July. "Uneven growth of urbanization in Iran. In", IUSSP XXV International Population Conference, and Tours, France, pp. 18e23.

26. Larsson, L. and Muller, D.K. (2017), "Coping with second home tourism: responses and strategies of private and public service providers in Western Sweden", Current Issues in Tourism, Vol. 22 No. 16, pp. 1958-1974.

27. Long, D.P., Hoogendoorn, G., 2013. Second home owners' perceptions of a polluted environment: the case of Hartbeespoort. South Afr. Geogr. J. 95 (1), 91-104.

28. McIntyre, N., Williams, D. R., \& McHugh, K. E. (Eds.). (2006), "Multiple dwelling and tourism: negotiating place, home and identity", Wallingford: CABI.

29. Michas G. (2021), "The new projects in tourism and the restart of the second home tourism", Oikonomia, May 2021 
30. Müller, D. K., \& Hall, C. M. (2003), "Second Homes and Regional Population Distribution: On Administrative Practices and Failures in Sweden”, Espace, Populations, Sociétés, 2003(2), 251261.

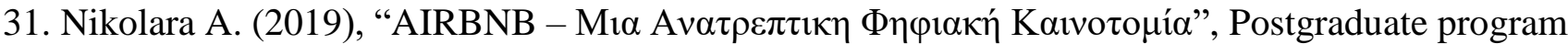
"Digital Innovation and Entrepreneurship", Department of Information and Communication Systems Engineering UNIVERSITY OF THE AEGEAN

32. Nordbø, I. (2014). "Beyond the transfer of capital? Second-home owners as competence brokers for rural entrepreneurship and innovation”. European Planning Studies, 22, 1641-1658. doi:10. $1080 / 09654313.2013 .784608$

33. Oman C. \& Arndt C. (2010), "Measuring Governance," OECD Development Centre Policy Briefs 39, OECD Publishing

34. Overvåg, K., \& Gunnerud Berg, N. (2011). "Second homes, rurality and contested space in Eastern Norway". Tourism Geographies, 13, 417-442.

35. Ritchie B \&. Crouch G. I. (2003), "The Competitive Destination: A Sustainable Tourism Perspective", CAB International

36. Robertsson, L., \& Marjavaara, R. (2015). "The seasonal buzz: Knowledge transfer in a temporary setting”. Tourism Planning \& Development, 12, 251-265. doi:10.1080/21568316.2014.947437

37. Roca, Z. (2013), "Second Home Tourism in Europe: Lifestyle Issues and Policy Responses", Ashgate, Farnham.

38. Rye, J.F., (2011). "Conflicts and contestations. Rural populations' perspectives on the second homes phenomenon”. J. Rural Stud. 27 (3), 263-274.

39. Said C (2012), "Short-term rentals disrupting the SF housing market". San Francisco Chronicle SFGate

40. Stergiou Dimitrios P, Papatheodorou Andreas and Tsartas Paris (2017), "Second home conversion during the economic crisis: the case of Artemida, Greece", Social \& Cultural Geography, 2017, Taylor and Francis Group, Vol. 18, No. 8, 1129-1151

41. The World Bank Annual Report 2015. Washington, DC. (C) World Bank.

42. Tilaki, M.M., Abdullah, A., Bahauddin, A., Marzbali, M.H., (2013), "Contemporary urbanization review: to identify the impact of policies and events on the evolution of urbanization in Iran". Middle East J. Sci. Res. 14 (11), 1452e1462.

43. Vagena, A. (2021). "Digital Nomads and Tourism Industry", Academia Letters, Article 765, https://doi.org/10.20935/AL765.

44. Vagionis N. \& Leontidou L. (2020), "Mediterranean Cultural and Residential Tourism: Alternative Forms Confronting Seasonality and Vulnerability", Region \& Periphery Issue 2020 (10), 71-102

45. Visser, G. (2008), "South Africa has second homes too! an exploration of the unexplored", Current Issues in Tourism, Vol. 9 Nos 4/5, pp. 351-383.

46. Wong B.K.M. et al. (2017), "Malaysia my second home: The influence of push and pull motivationson satisfaction", Tourism Management 61 394-410

47. Zogal V., Domenech A., Emekli G. (2020), "Stay at (which) home: second homes during and after the COVID-19 pandemic", Journal of Tourism Futures, ISSN: 2055-5911

48. Zorica Lončar (2021)," Buying property in Greece as a foreigner”, https://wise.com/gb/blog/buyproperty-in-greece

49. https://www.newmoney.gr/roh/palmos-oikonomias/tourismos/afximeno-endiaferon-gia-akinitasta-ellinika-nisia/ 